

\title{
A reconsideration of tourism specialization in Europe
}

Jean-Jacques Nowak, Sylvain Petit

\section{To cite this version:}

Jean-Jacques Nowak, Sylvain Petit. A reconsideration of tourism specialization in Europe. Tourism Economics, In press, 10.1177/1354816620937508 . hal-02900225

\section{HAL Id: hal-02900225 \\ https://hal.science/hal-02900225}

Submitted on 15 Jul 2020

HAL is a multi-disciplinary open access archive for the deposit and dissemination of scientific research documents, whether they are published or not. The documents may come from teaching and research institutions in France or abroad, or from public or private research centers.
L'archive ouverte pluridisciplinaire HAL, est destinée au dépôt et à la diffusion de documents scientifiques de niveau recherche, publiés ou non, émanant des établissements d'enseignement et de recherche français ou étrangers, des laboratoires publics ou privés. 


\title{
A reconsideration of tourism specialization in Europe
}

\author{
Nowak Jean-Jacques
}

Ass. Professor

RIME Lab, University of Lille, France

\section{Petit Sylvain}

Ass. Professor, corresponding author ${ }^{1}$

CETOP-GDI, University of French Polynesia

CRISS, Polytechnic University Hauts de France

CRESEM, Université de Perpignan Via Dominitia

${ }^{1}$ Tél.: (+689) 40-86-64-32 GMT -10:00 ; B.P. 6570 - 98702 Faa’a - Tahiti - Polynésie française sylvain.petit@upf.pf

sylvain.petit@phf.fr 


\title{
A reconsideration of tourism specialization in Europe.
}

\begin{abstract}
.
Tourism specialization has been studied so far at an aggregate geographical level and by considering tourism as a homogeneous product. The result is a simplistic and stereotypical image of tourism specialization, as for Europe where southern EU countries are commonly viewed as highly specialized in tourism services and northern EU countries highly specialized in other activities. The purpose of this paper is to provide a method for a deeper analysis of tourism specialization. We study comparative advantages and disadvantages of a sample of twenty European countries over the period 2010-2016 by considering bilateral flows of three different quality tourism services (high, middle, low). Our results show serious differences with those obtained by the traditional approach.
\end{abstract}

Keywords: tourism trade, tourism specialization, differentiation by quality, bilateral trade, comparative advantages 


\section{Introduction}

The aim of this article is to provide a method for a deeper analysis of tourism specialization, with an application to Europe. Studying tourism specialization is an important issue. First, it amounts to identify and measure the tourism competitiveness of a destination. Second, it could help to understand why empirical results on the tourism-growth nexus are mixed: according to Chiu and Yeh (2017), these mixed results could be due to the inadequate way tourism specialization is usually defined and measured. Third, as a worldwide export category, tourism services rank third after chemicals and fuels, and are the top export category for many countries. Yet very little is known on international trade and patterns of specialization in tourism services, as compared to trade in merchandise. Fourth, the tourism industry is very strongly impacted by the COVID-19 pandemic. Destinations are already all affected, but in different ways and to different degrees. The study of tourism specialization could help to understand these differences.

The few existing academic studies (e.g. Algieri, Aquino \& Succurro, 2016, and references within) display two major shortcomings. First, the analysis is usually conducted at a multilateral level (e.g. one country with respect to the rest of the world), giving rise to the risk of spurious conclusions due to a geographical aggregation bias. As has been known since at least the 1950's in the context of the Leontief paradox (Tatemoto \& Ichimura, 1959), the appropriate level of analysis for international specialization is the bilateral one. Second, tourism is always considered as a homogeneous product. Yet available evidence suggests that tourism is a highly differentiated product, in particular regarding the dimension of quality (Hanna, Lévi \& Petit, 2015). This could have serious implications on the way tourism influences economy. For example, Albaladejo Pina \& Martínez-García (2014) showed that the quality of tourist services is important in maintaining tourism's role in promoting long-term growth. In this article, we propose to shed new light on specialization in tourism by using a 
methodology addressing these two shortcomings, with an application to the European Union. This article is organized as follows. Section 2 described the index used to measure tourism specialization. Section 3 presents the results when using bilateral data. Section 4 adds vertical differentiation to the measure of specialization.

\section{How to measure tourism specialization traditionally?}

We analyze tourism specialization patterns on a strict bilateral level (each country with respect to each of its partners separately) and we introduce quality in tourism trade through the definition of three market segments (high $\mathrm{H}$, middle $\mathrm{M}$, low L). The study relates to a sample of twenty European countries (selected on the basis of data availability) over the period 2010-2016 and is based on bilateral intra-European trade flows (exports and imports) in tourism services from the OECD database. Mirrored data (exports to $\mathrm{j}$ reported by $\mathrm{i}$ and imports from i reported by j) were harmonized by using the method developed by Lejour \& Verheijden (2004).

We chose to measure comparative advantages in tourism by using the "contribution to the trade balance" indicator (CTB) developed by the Centre d'Etudes Prospectives et d'Informations Internationales (CEPII) (Lafay, 1992). This indicator has been preferred to the standard Balassa index as it combines together trade and production variables, and displays better empirical distribution characteristics.

The CTB index of country $i$ for tourism quality $s(s=\mathrm{H}, \mathrm{M}, \mathrm{L})$ will be computed for each year $t$ with each of its $19 j$ partners separately:

$$
C T B_{i j t}^{S}=\frac{1000}{G D P_{i t}} \cdot\left[\left(X_{i j t}^{S}-M_{i j t}^{S}\right)-\left(\left(\frac{X_{i j t}^{S}+M_{i j t}^{S}}{X_{i j t}+M_{i j t}}\right) \cdot\left(X_{i j t}-M_{i j t}\right)\right)\right]
$$


with:

$X_{i j t}^{S}\left(M_{i j t}^{S}\right)$ : exports (imports) of tourism services of quality $s(\mathrm{~s}=\mathrm{H}, \mathrm{M}, \mathrm{L})$ by country $i$ to (from) country $j$ in year $t$,

$X_{i j t}\left(M_{i j t}\right)$ : total exports (imports) of goods and services by country $i$ to (from) country $j$ in year $t$,

$G D P_{i t}$ : gross domestic product of country $i$ in year $t$.

There are $19 C T B_{i j t}^{S}(\mathrm{~s}=\mathrm{H}, \mathrm{M}, \mathrm{L})$ for each country $i$. Note that $C T B_{i j t}=C T B_{i j t}^{H}+C T B_{i j t}^{M}+$ $C T B_{i j t}^{L}$

A positive value for $C T B_{i j t}^{S}$ reveals a comparative advantage for country $i$ with respect to country $j$ for tourism services of quality $s$ in year $t$, whereas a negative value indicates a comparative disadvantage.

However, for the sake of comparability, let us start by analysing tourism specialization in the usual way, i.e. at a multilateral level and with tourism considered as a homogeneous product (no difference in quality). In equation (1), superscripts $s$ and $j$ have to be removed as we consider exports of total tourism services, irrespective of their quality, by country $i$ to its 19 European partners taken together and its imports from the same set of 19 partners. Column 1 of table 1 shows the mean values of the $C T B_{i}$ over 2010-2016. The results are similar to those of previous studies and confirm the usual and unequivocal image of a strong tourism specialization of southern EU countries (Greece, Portugal, Spain, Slovenia), and serious comparative disadvantages for northern and most central EU countries (Belgium, Germany, Sweden, UK, Poland, Slovakia). 


\section{Tourism specialization at the bilateral level}

Let us analyse tourism specialization at a bilateral level, but still with no difference in quality. Subscript $j$ has to be reintroduced in equation (1) in order to compute a $C T B_{i j t}$ indicator for each country $i$ for each year $\mathrm{t}$ with each of its $19 \mathrm{j}$ partners separately. Column 2 of table 1 shows the annual frequency of bilateral comparative advantages in tourism for each country (mean over 2010-2016). Several results can be drawn. First, no country displays either only comparative advantages or only comparative disadvantages when considering its partners separately. All countries displaying a comparative advantage (disadvantage) for tourism at the multilateral level simultaneously display comparative disadvantages (advantages) with some countries. Second, the diagnosis on a country's tourism specialization made on a multilateral basis can be challenged on a bilateral basis. Consider the case of the UK: its multilateral $C T B_{i}$ $(-1.8)$ indicates a comparative disadvantage in tourism over the period while this country displayed comparative advantages in $57.7 \%$ cases on average, as much as Austria (56.5\%) which has a high positive multilateral $C T B_{i}(+14.9)$. Therefore, it could be legitimately claimed that the UK is specialised in tourism. The opposite can be said for the Netherlands: no specialization in tourism despite a multilateral $C T B_{i}$ of +3 as it displayed comparative advantages in only $7.3 \%$ cases. Third, the degree of specialization diagnosed on a multilateral basis is also questionable when considered on a bilateral basis (e.g. compare France to Estonia, Slovenia to Italy, Sweden to Finland). These results confirm a geographical bias when tourism specialization is measured by using aggregate data.

\section{Tourism specialization across ranges of quality}

As the final step, let us analyse tourism specialization at a bilateral level and along ranges of quality. We follow here Fleischer and Rivlin (2009) by assuming that, in tourism, differences in quality are reflected by differences in unit values, i.e. the average tourist vacation 
expenditure per day. As we consider tourism exports, differences in quality will be supposed to be proxied by differences in export unit values. The unit value of country $i$ 's exports to country $j\left(E U V_{i j}\right)$ can be defined for each bilateral tourism trade flow (from $i$ to $j$ ) as the average spending per day in $i$ by a tourist from $j$. Following Hanna, Lévi \& Petit (2015), it is obtained by the ratio of the tourism export receipts of $i$ from $j$ divided by the number of total nights spent by $j$ 's travellers in $i$ (overnight stays from UNWTO database) deflated by a purchasing power quality index (World Bank database).

The three ranges of quality $(\mathrm{H}, \mathrm{M}, \mathrm{L})$ are defined by comparing these export unit values to a norm, $\overline{E U V}$, the export-weighted harmonic mean of export unit values over all flows of the sample. If the export unit value is close to $\overline{E U V}$, then the tourist flow can be considered to be mainly of medium quality (range $\mathrm{M}$ ); if the value is above this norm, then the flow is considered to be mainly of high quality (range $\mathrm{H}$ ); and if the value is below this norm, then the flow is considered to be mainly of low quality (range L).

However, to avoid both threshold effects and the unrealistic classification of each tourism flow in a single range of quality, we use the following method, adapted from Fontagné, Gaulier \& Zignago (2008), which allows to divide each tourism flow into the three ranges. For each tourism export flow (from $i$ to $j$ ), we define its relative export unit value $r_{i j}$ as $r_{i j}=\frac{E U V_{i j}}{\overline{E U V}}$

If $r_{i j}<1$, then the value of the tourism export flow $(i, j)$ is divided into middle (M), low (L) and high $(\mathrm{H})$ ranges as follows:

- the flow's share of middle range is $\beta . r_{i j}{ }^{\alpha}$, with $\alpha>0,0<\beta<1$

- the flow's share of low range is $1-\left(\gamma \cdot r_{i j}{ }^{\alpha}\right)$ with $0<\gamma<1$

- the flow's share of high range is $(\gamma-\beta) \cdot r_{i j}{ }^{\alpha}$.

If $r_{i j}>1$, then the distribution of the tourism export flow is as follows: 
- the flow's share of middle range is $\beta \cdot \frac{1}{r_{i j}{ }^{\alpha}}$

- the flow's share of low range is $(\gamma-\beta) \cdot \frac{1}{r_{i j}{ }^{\alpha}}$

- the flow's share of high range is $1-\left(\gamma \cdot \frac{1}{r_{i j}{ }^{\alpha}}\right)$.

The parameters $\alpha, \beta$ and $\gamma$ have been chosen to minimize the differences of shares of tourism trade between the three ranges: $\alpha=2, \beta=0.7$ and $\gamma=0.85$. (Simulations with other values give similar final results and are available upon request.)

Finally, equation (1) is computed for each pair of countries and each quality. Columns (3), (4) and (5) of table 1 give the mean over 2010-2016 of annual frequencies (as share of total bilateral flows) of bilateral comparative advantages by range of quality. Taking quality into consideration strengthens the results of the previous step: all countries display comparative advantages and disadvantages at the same time, mostly in an even larger proportion than before (compare columns 2 and 6). Countries specialized in tourism according to the multilateral aggregate approach (e.g. Greece, Portugal, Spain) have a lower frequency of bilateral comparative advantages than without considering quality, while it is generally the opposite for countries known as non-specialized (e.g. Belgium, Finland, Germany).

Moreover, the results clearly show that tourism specialization is a more subtle phenomenon than suggested by the standard approach, taking place in Europe within the tourism sector itself, along the spectrum of quality. This is perfectly illustrated by the cases of France and the Netherlands. Although both countries have almost the same multilateral aggregate comparative advantage $(+2.3$ and +3.0 respectively), France appears to be mainly specialized in the lower segment (30.8\% of comparative advantages in total bilateral flows, against $3.4 \%$ for the upper segment) while the Netherlands are almost completely specialized in the upper segment (21.7\% against $2.2 \%$ for the other two segments). Finland is another striking case: classified as non-specialized in tourism by usual standards (-2.8), this country is, along with 
Greece, the most specialized in high-quality tourism (26.1\% of comparative advantages in total cases). Many northern EU countries follow a similar pattern (e.g. Germany) and prove to be at least as specialized in up-quality tourism as high positive $C T B_{i}$ countries. These results indicate that considering tourism as a quality-differentiated product within bilateral flows leads to a more complex picture of tourism specialization in Europe than is commonly accepted.

Table 1. Comparative advantages in tourism, 2010-2016

\begin{tabular}{|c|c|c|c|c|c|c|}
\hline & \multirow{3}{*}{$\begin{array}{l}\quad C T B_{i} \\
\text { (mean value, } \\
\text { multilateral) } \\
\text { (1) } \\
\text { No difference } \\
\text { in quality }\end{array}$} & \multicolumn{5}{|c|}{ Frequency of CA (mean of annual values) (bilateral, \%) } \\
\hline & & (2) & (3) & (4) & (5) & (6) \\
\hline & & $\begin{array}{l}\text { No difference } \\
\text { in quality }\end{array}$ & High range & $\begin{array}{l}\text { Middle } \\
\text { range }\end{array}$ & Low range & $\begin{array}{l}\text { Total } \\
(3+4+5)\end{array}$ \\
\hline Austria & $14.9(3)$ & $56.5(10)$ & $17.2(9)$ & 19.5 (8) & 17.5 (10) & $53.8(8)$ \\
\hline Belgium & $-11.3(20)$ & 7.7 (19) & $14.4(12)$ & $2.5(18)$ & $2.5(18)$ & 19.4 (19) \\
\hline Czech Rep. & $-1.6(11)$ & $38.9(12)$ & $11.0(15)$ & $14.7(11)$ & $17.4(11)$ & $43.2(11)$ \\
\hline Denmark & $-3.2(15)$ & $42.3(11)$ & 9.3 (16) & $17.7(9)$ & $15.5(13)$ & $42.5(12)$ \\
\hline Estonia & $12.7(6)$ & $64.9(7)$ & $17.1(10)$ & $23.6(6)$ & $22.8(6)$ & $63.4(6)$ \\
\hline Finland & $-2.8(14)$ & $8.4(18)$ & $26.1(2)$ & $1.9(20)$ & $1.2(20)$ & $29.3(17)$ \\
\hline France & $2.3(10)$ & $67.8(5)$ & $3.4(20)$ & $13.4(13)$ & $30.8(2)$ & $47.6(10)$ \\
\hline Germany & $-9.7(19)$ & 9.9 (17) & $21.6(6)$ & 4.2 (16) & $4.2 \quad(16)$ & $30.0(15)$ \\
\hline Greece & $37.0(1)$ & 98.0 (1) & 26.2 (1) & 31.6 (1) & 31.7 (1) & 89.5 (1) \\
\hline Hungary & $5.2(8)$ & $64.7(8)$ & $13.0(13)$ & $25.1(3)$ & $27.4(4)$ & $65.5(5)$ \\
\hline Italy & 5.4 (7) & 70.4 (4) & $17.3(8)$ & $24.1(7)$ & $19.3(8)$ & $60.7(7)$ \\
\hline Luxembourg & $-8.0(18)$ & $14.2(16)$ & 5.7 (19) & 3.2 (17) & 3.2 (17) & $12.1(20)$ \\
\hline Netherlands & 3.0 (9) & $7.3 \quad(20)$ & $21.7(4)$ & 2.2 (19) & 2.2 (19) & $26.0(18)$ \\
\hline Poland & $-2.2(13)$ & $21.8(14)$ & $7.0 \quad(18)$ & $11.5(14)$ & $13.8(14)$ & $32.3(14)$ \\
\hline Portugal & $24.8(2)$ & $90.2(2)$ & $21.7(5)$ & $31.3(2)$ & $28.4(3)$ & $81.3(2)$ \\
\hline Slovak Rep. & $-5.8(17)$ & $19.7(15)$ & 8.5 (17) & $14.5(12)$ & $17.1(12)$ & $40.1(13)$ \\
\hline Slovenia & 12.7 (5) & $67.3(6)$ & $19.2(7)$ & $23.8(5)$ & $23.6(5)$ & $66.6(4)$ \\
\hline Spain & $12.8(4)$ & $76.9(3)$ & $24.6(3)$ & $24.0(4)$ & $20.3(7)$ & $68.9(3)$ \\
\hline Sweden & $-3.4(16)$ & $35.2(13)$ & $16.7(11)$ & 6.5 (15) & 6.5 (15) & $29.7(16)$ \\
\hline UK & $-1.8(12)$ & 57.7 (9) & $12.6(14)$ & $17.1(10)$ & $18.6(9)$ & $48.3(9)$ \\
\hline
\end{tabular}

Source: computed from OECD, UNWTO and World Bank databases.

Note: for each column, the countries' ranking is in brackets. 
Finally, this new method of analysis can help to identify the nature and the form of specialisation in tourism, besides the degree. In the context of the COVID-19 pandemic, it might be interesting to compare the different impacts of the crisis on destinations according to the nature of their specialisation. For example, it would be worth studying if a specialisation in high-quality tourism could help a country to adjust in a less painfull way than a specialization in mass, low-quality tourism.

\section{References}

Albaladejo, I. P., González-Martínez, M. I., \& Martínez-García, M. P. (2014). Quality and endogenous tourism: An empirical approach. Tourism Management, 41, 141-147.

Algieri, B., Aquino, A., \& Succurro, M. (2016). Drivers of comparative advantages in tourism: The eu-case. Annals of Tourism Research, 6(3), 247-250.

Chiu, Y-B. \& Yeh, L.-T. (2017). The Threshold Effects of the Tourism-Led Growth Hypothesis: Evidence from a Cross-sectional Model. Journal of Travel Research, 56(5), 625637.

Fleisher, A. \& Rivlin, J. (2009). More or Better? Quantity and Quality Issues in Tourism Consumption. Journal of Travel Research, 47(3), 285-294.

Fontagné, F., Gaulier, G. \& Zignago, S. (2008). Specialization across varieties and NorthSouth competition. Economic Policy, 23(53), 51-91.

Hanna, J., Lévi, L. \& Petit, S. (2015). Intra-tourism trade, income distribution and tourism endowment: an econometric investigation. Applied Economics, 47(21), 2184-2200.

Lafay, G. (1992). The Measurement of Revealed Comparative Advantages. In M.G. Dagenais \& P-A. Muet (Eds.), International Trade Modelling (pp.209-234). London: Chapman \& Hall. 
Lejour, A., \& De Paiva Verheijden, J-W. (2004). Services trade within Canada and the European Union. What do they have in common? Discussion Paper 42. The Hague: Centraal Plan Bureau.

Tatemoto, M. \& Ichimura, S. (1959). Factor Proportions and Foreign Trade: The Case of Japan. The Review of Economics and Statistics, 41(4), 442-446. 